\title{
"Geopolimeros": una única base química y diferentes microestructuras
}

\section{"Geopolymers": same basic chemistry, different microstructures}

A. PALOMO, A. FERNÁNDEZ-JIMÉNEZ, M. CRIADO

Instituto de Ciencias de la Construcción Eduardo Torroja (CSIC)

Persona de contacto/Corresponding author: palomo@ietcc.csic.es

Fecha de recepción: 24-IX-03

Fecha de aceptación: 8-III-04

ESPAÑA

RESUMEN

Este trabajo describe el efecto de determinadas variables de trabajo sobre la evolución microestructural de sistemas basados en cenizas volantes térmica y alcalinamente activadas. Los resultados demuestran que el principal producto de reacción en el proceso de activación (en todos los sistemas estudiados) es un aluminosilicato amorfo con caracteristicas de gel y con estructura tridimensional. Sin embargo el tipo y la concentración del activador usado, así como el envejecimiento natural de los materiales y el origen diferente de las materias primas han demostrado también ser variables que afectan sustancialmente al desarrollo microestructural de los "geopolimeros" sintetizados especialmente desde el punto de vista morfológico.

\section{SUMMARY}

The present paper describes the effect of certain working variables on the microstructural evolution of oven-dried, alkali-activated fly ash. The results show that the main reaction product in the activation process (in all the systems studied) is an amorphous aluminosilicate gel with a threedimensional structure. Nonetheless, the type and concentration of the activator used as well as the natural ageing of the materials and origin of the prime materials were also found to have a substantial impact on microstructural development in the "geopolymers" synthesised, particularly from the morphological standpoint.
PALABRAS CLAVE: ceniza volante, metacaolín, activación alcalina, microestructura.

\section{INTRODUCIÓN}

Es bien conocido que la activación alcalina de escorias de alto horno produce el fraguado y el endurecimiento de las mismas, como si de un cemento Portland se tratara (1-3). Completamente diferente, sin embargo, es la activación alcalina de cenizas volantes. En este caso se habla de un proceso químico por el cual el componente vítreo de este subproducto industrial se transforma también en un material compacto caracterizado por sus excelentes propiedades ligantes y el magnifico desarrollo de propiedades mecánicas,
KEYWORDS: fly ash, metakaolin, alkaline activation, microstructure.

\section{INTRODUCTION}

When blast furnace slag is alkali-activated it is known to set and harden in much the same way as Portland cement does (1-3). The alkali-activation offly ash, however, is completely different. In this case, the chemical process involved cortiverts the vitreous component of this industrial by-product into a compact material characterised not only by its Portland 
como si se tratara de un cemento Portland, pero también caracterizado por determinadas propiedades específicas de las cerámicas y las zeolitas (4-8).

Es más, el material en estado fresco es perfectamente trabajable, permitiendo usar bajas relaciones líquido/ sólido. Desde el punto de vista microestructural los productos finalmente obtenidos dependen de la disolución inicial en la que se disuelve la ceniza y de la condensación de las especies iónicas formadas. En este proceso los geles tixotrópicos generados polimerizan hasta alcanzar su forma final (9-12).

Este trabajo está relacionado con los distintos "geopolímeros" que se obtienen a partir de las cenizas volantes procedentes de la combustión del carbón. La solidificación de las cenizas activadas se piensa que es una consecuencia de un conjunto de procesos disolución-condensación en los que se estabiliza una estructura tridimensional de tetraedros de silicatos rodeados por tetraedros de aluminatos y distribuidos al azar (11-12). Estos sistemas en los que la red está negativamente cargada debido a la incorporación de las unidades tetraédricas $\mathrm{AlO}_{4}$ requieren de las correspondientes cargas positivas que compensen el balance de cargas y que son aportadas por los cationes alcalinos que se incorporan en la matriz del "geopolímero".

\section{OBJETIVO}

El principal objetivo de la presente investigación fue el de demostrar que los "geopolímeros" constituyen una familia de materiales con una base química común pero con diferentes microestructuras. Con el objeto de alcanzar este objetivo general, en el momento de planificar la experimentación a realizar se tuvieron en consideración un conjunto de variables de trabajo: tipo de activador, concentración del activador, envejecimiento del "geopolímero" y naturaleza de las materias primas de partida.

\section{PARTE EXPERIMENTAL Y RESULTADOS}

La mayoría de la experimentación llevada a cabo en este trabajo se ha realizado con una ceniza volante tipo F procedente del sur de España. El análisis químico de la ceniza se da en la Tabla 1; y algunas de sus características físicas se pueden observar en las Tablas 2 y 3 . Un aspecto general de la microestructura de la ceniza, así como algunos detalles de la misma pueden observarse en la Figura 1.

Esta ceniza es básicamente un material vítreo con algunas fases cristalinas minoritarias tales como la cement-like binding properties and mechanical strength, but by certain specific properties typical of ceramic materials and zeolites as well (4-8).

In addition, the fresh material is readily workable even at low liquid/solid ratios. From the microstructural standpoint, the final products obtained depend on the initial solution in which the ash is dissolved and the condensation of the unstable ionic species formed. The initial thixotropic gels are polymerised to their final form in this process (9-12).

This paper deals with the different "geopolymers" obtained from a coal combustion by-product. The solidification of activated fly ash is thought to be the result of a series of solution-polycondensation processes that stabilise in the form of a randomly arranged three-dimensional network of corner-linked silicate and aluminate tetrahedra (11-12). The alumino-silicate skeleton of these systems bears a negative charge - generated by the inclusion of the $\mathrm{AlO}_{4}$ tetrahedra - which is balanced by the alkaline cations, which are therefore tightly bound to the "geopolymer matrix".

\section{OBJECTIVE}

The primary objective of the present study was to show that "geopolymers" comprise a family of materials with the same basic chemical composition but different microstructures. With this overall objective in mind, the experimental design was formulated taking account of a series of working variables, namely: activator type and concentration, "geopolymer" ageing and nature of prime materials.

\section{EXPERIMENTAL AND RESULTS}

Most of the experiments were conducted with type F fly ash from southern Spain. The chemical analysis of the ash is given in Table 1 and some of its physical properties in Tables 2 and 3. Figure 1 shows an overview as well as certain details of ash microstructure.

This ash is essentially a vitreous material with certain minority crystalline phases such as mullite, 
TABLA 1/TABLE 1

Composición química de la ceniza volante

Chemical composition of the fly ash

\begin{tabular}{|c|c|c|c|c|c|c|c|c|c|c|}
\hline $\begin{array}{c}\text { Oxido } \\
\text { Oxide }\end{array}$ & $\mathrm{SiO}_{2}$ & $\mathrm{Al}_{2} \mathrm{O}_{3}$ & $\mathrm{Fe}_{2} \mathrm{O}_{3}$ & $\mathrm{CaO}$ & $\mathrm{MgO}$ & $\mathrm{Na}_{2} \mathrm{O}$ & $\mathrm{K}_{2} \mathrm{O}$ & $\mathrm{SO}_{3}$ & L.O.I* & Insol. \\
\hline$\%$ & 54.42 & 26.42 & 7.01 & 3.21 & 1.79 & 0.59 & 3.02 & 0.01 & 2.19 & 0.78 \\
\hline
\end{tabular}

L.O.I. = Pérdida por calcinación/Loss on ignition

Insol. $=$ Residuo insoluble /Insoluble residue

TABLA 2/TABLE 2

Finura de la ceniza volante por tamizado Fly ash fineness by sieving

\begin{tabular}{|c|c|}
\hline $\begin{array}{c}\text { Luz del tamiz } \\
\text { Mesh light of sieves }\end{array}$ & $\begin{array}{c}\% \text { retenido } \\
\% \text { retained }\end{array}$ \\
\hline $210 \mu \mathrm{m}$ & 1.02 \\
\hline $125 \mu \mathrm{m}$ & 4.27 \\
\hline $90 \mu \mathrm{m}$ & 1.63 \\
\hline $45 \mu \mathrm{m}$ & 14.23 \\
\hline$<45 \mu \mathrm{m}$ & 78.86 \\
\hline
\end{tabular}

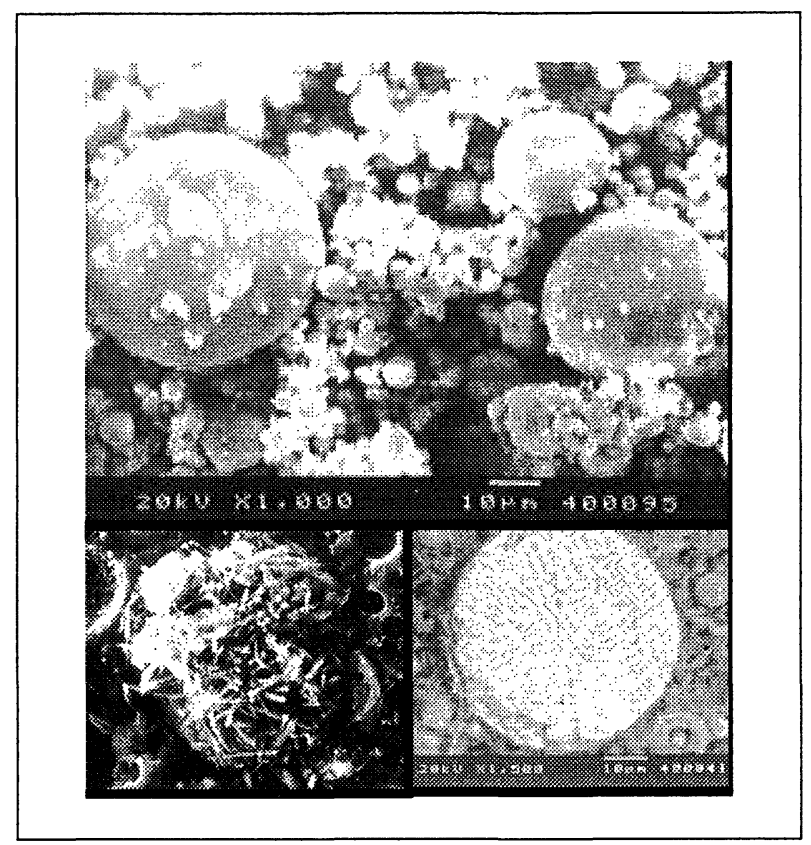

Figura 1.-Ceniza volante original.

Figure 1.- Starting fly ash.

TABLA 3/TABLE 3

Densidad y superficie especifica

Density and specific surface

\begin{tabular}{|c|c|}
\hline Densidad $\left(\mathrm{g} / \mathrm{cm}^{3}\right) /$ Density $\left(\mathrm{g} / \mathrm{cm}^{3}\right)$ & 2.33 \\
\hline Blaine $\left(\mathrm{m}^{2} / \mathrm{kg}\right) /$ Blaine $\left(\mathrm{m}^{2} / \mathrm{kg}\right)$ & 202 \\
\hline BET $\left(\mathrm{m}^{2} / \mathrm{kg}\right) /$ BET $\left(\mathrm{m}^{2} / \mathrm{kg}\right)$ & 510 \\
\hline
\end{tabular}

mullita, el cuarzo y la magnetita. El contenido de sílice reactiva es aproximadamente del $45 \%$.

\subsection{Efecto del tipo de activador sobre la microestructura del producto final}

Fueron utilizadas cuatro disoluciones alcalinas diferentes para activar la ceniza volante: a) disolución de $\mathrm{KOH}, \mathrm{b}$ ) disolución de $\mathrm{NaOH}, \mathrm{c}$ ) mezcla de disolución de $\mathrm{NaOH}$ con "waterglass" $(85 \%+15 \%$ respectivamente), d) mezcla de lentejas de $\mathrm{NaOH}$ con "waterglass" $(15 \%+85 \%)$. quartz and magnetite. Reactive silica accounts for approximately $45 \%$ of the content.

\subsection{Impact of activator on the microstructure of the final product}

Four different alkaline solutions were used to activate the fly ash: 1) $\mathrm{KOH}$ solution, b) $\mathrm{NaOH}$ solution, c) mixture of $\mathrm{NaOH}$ solution and "waterglass" $(85 \%+15 \%$, respectively), d) mixture of $\mathrm{NaOH}$ pellets and waterglass $(15 \%+85 \%)$. 
La totalidad de los activadores alcalinos se prepararon con productos químicos comerciales de uso común en el laboratorio. La concentración de las cuatro disoluciones activadoras se mantuvo constante y equivalente a la concentración de una disolución alcalina de $8 \mathrm{M}$ en $\mathrm{MOH}$.

El procedimiento seguido en todos los casos para la preparación de los "geopolímeros" fue el de mezclar la ceniza volante con la disolución activadora y posterior curado de la pasta resultante en estufa a $85^{\circ} \mathrm{C}$ durante 20 horas. El material obtenido fue estudiado por microscopia electrónica de barrido.

\section{a) $\mathrm{KOH}(8 M)$}

En la Figura 2 se muestra la microestructura de un sistema activado con $\mathrm{KOH} 8 \mathrm{M}$. Cuando la potasa ataca al componente vítreo de la ceniza el producto de reacción permanece adherido a las partículas originales de la ceniza. No hay dispersión del producto alrededor del sistema y, consecuentemente, muchos huecos y poros permanecen sin rellenar. En dicha Figura 2 se puede observar una cantidad relativamente alta de poros así como de partículas de ceniza sin reaccionar.

Otra información interesante extraída del estudio microscópico es la relativa a la composición química del producto de reacción: silicoaluminato potasio con una relación $\mathrm{Si} / \mathrm{Al}=1,7-1,8$ y con una relación $\mathrm{K} / \mathrm{Al}=0,8-0,9$

\section{b) $\mathrm{NaOH}(8 \mathrm{M})$}

Cuando el activador alcalino es una disolución de hidróxido sódico se puede observar también un número de poros relativamente alto y un conjunto de
All the alkali activators were prepared with standard commercial laboratory chemicals. The concentration of the four activating solutions was constant and equivalent to the concentration of an $8 \mathrm{MMOH}$ solution.

The procedure followed to prepare all the "geopolymers" was to mix the fly ash with the activating solution and oven-dry the resulting paste for 20 hours at $85^{\circ} \mathrm{C}$. The material obtained was studied under an scanning electron microscope.

\section{a) $8 \mathrm{M} \mathrm{KOH}$}

Figure 2 shows the microstructure of a system activated with $8 \mathrm{M} \mathrm{KOH}$. When the potash attacks the vitreous component of the ash the reaction products remain essentially "bound" to the spherical particles comprising the ash. As the product does not spread throughout the system, many voids and pores are not filled, leading to a relatively large number of empty pores and unreacted fly ash particles, as illustrated by the images in Figure 2.

Another interesting fact afforded by the microscopic study is the chemical composition of the reaction product: potassium silicoaluminate with a Si/Al ratio of around 1.7-1.8 and a K/Al ratio on the order of 0.8-0.9.

\section{b) $8 \mathrm{MAOH}$}

When the alkali activator is a sodium hydroxide solution, the result is also a product with a relatively large number of pores and a series of hollow spheres.

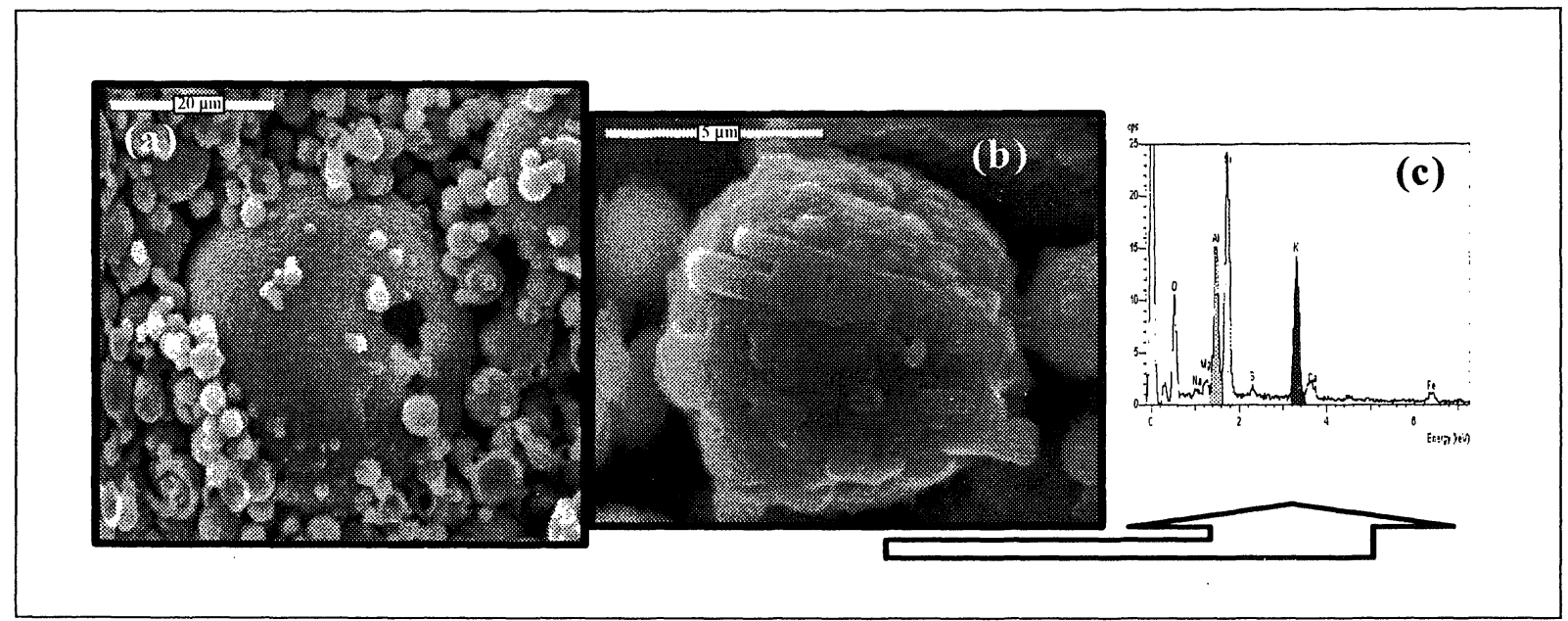

Figura 2.- . (a) Ceniza volante activada con $\mathrm{KOH} 8 \mathrm{M}$, (b) detalle del producto de reacción (c) análisis clemental.

Figure 2.- (a) Fly ash activated with an $8 M \mathrm{KOH}$ dissolution. (b) detail of the reaction product. (c) elemental analysis. 
esferas huecas. Sin embargo, en este caso, el producto de reacción se desprende de las esferas individuales formando una masa sólida heterogéneamente distribuida en contacto con partículas que no han reaccionado. También es interesante observar cómo algunas esferas de ceniza están parcialmente recubiertas por productos de reacción, lo cual podría sugerir que la precipitación de los productos de reacción puede formar, en un breve espacio de tiempo, una película sobre partículas sin reaccionar que dificultaría su posterior activación (ver Figura 3). Este hecho podría justificar el moderado grado de reacción alcanzado por este tipo de sistemas y previamente observado en otras investigaciones (13).

En estos sistemas de cenizas activadas con $\mathrm{NaOH}$ la presencia de pequeñas cantidades de zeolitas cristalinas del tipo herschelita ha sido igualmente detectada (Figura 4). Estas partículas cristalinas son más ricas en
Nonetheless, in this case the reaction product is released from the individual spheres to form an unevenly distributed solid mass in contact with unreacted particles. It is likewise interesting to note that some ash spheres are partially covered by reaction product, suggesting that in a very short period of time, precipitating reaction products may form a film over unreacted particles, hindering any subsequent activation (see Figure 3). This would explain the merely moderate degree of reaction observed in such systems in earlier research (13).

Small amounts of crystalline zeolites such as herschelite were also detected in these $\mathrm{NaOH}$-activated fly ash systems (Figure 4). These crystalline particles have a higher Si content than the rest of the matrix (the

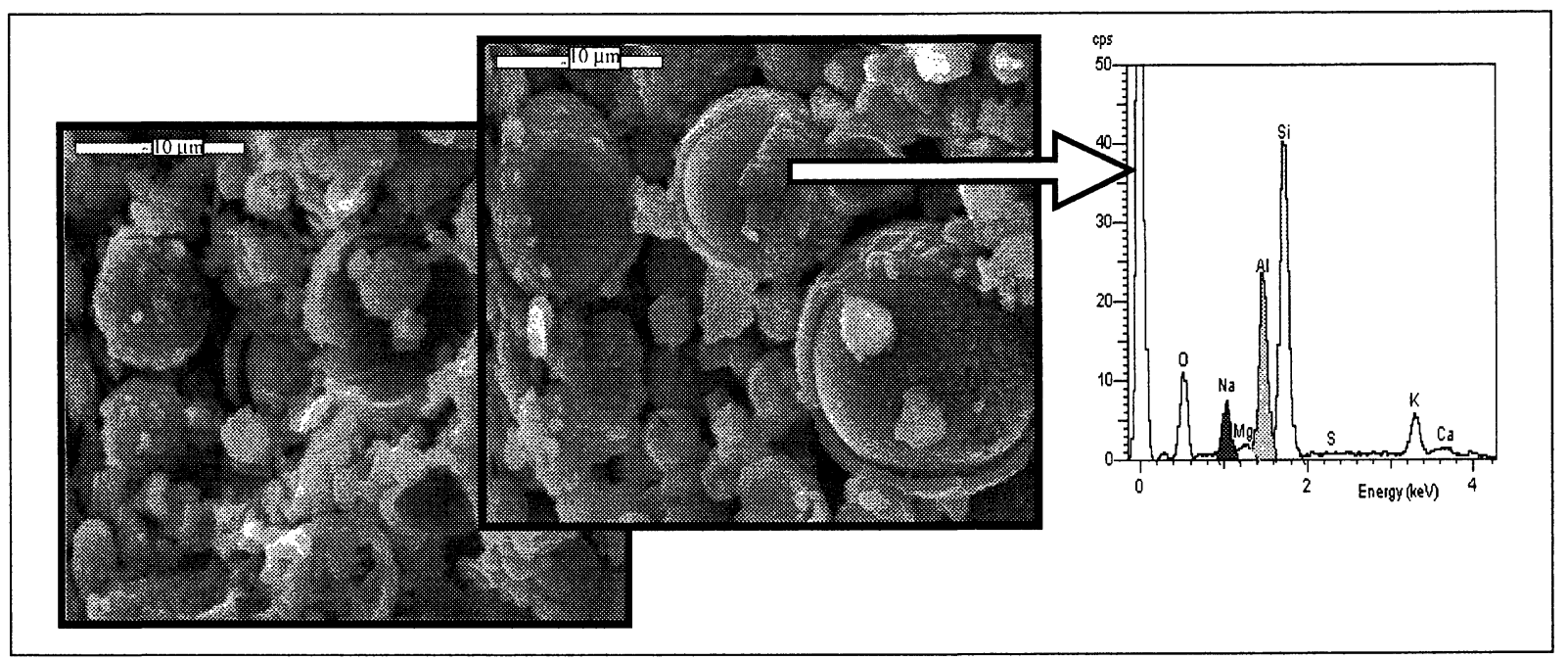

Figura 3.- Ceniza activada con $\mathrm{NaOH} 8 \mathrm{M}$, aspecto general y análisis elemental del producto de reacción.

Figure 3.- Fly ash activated with an $8 M \mathrm{NaOH}$ solution. general aspect, and elemental analysis of the reaction product.

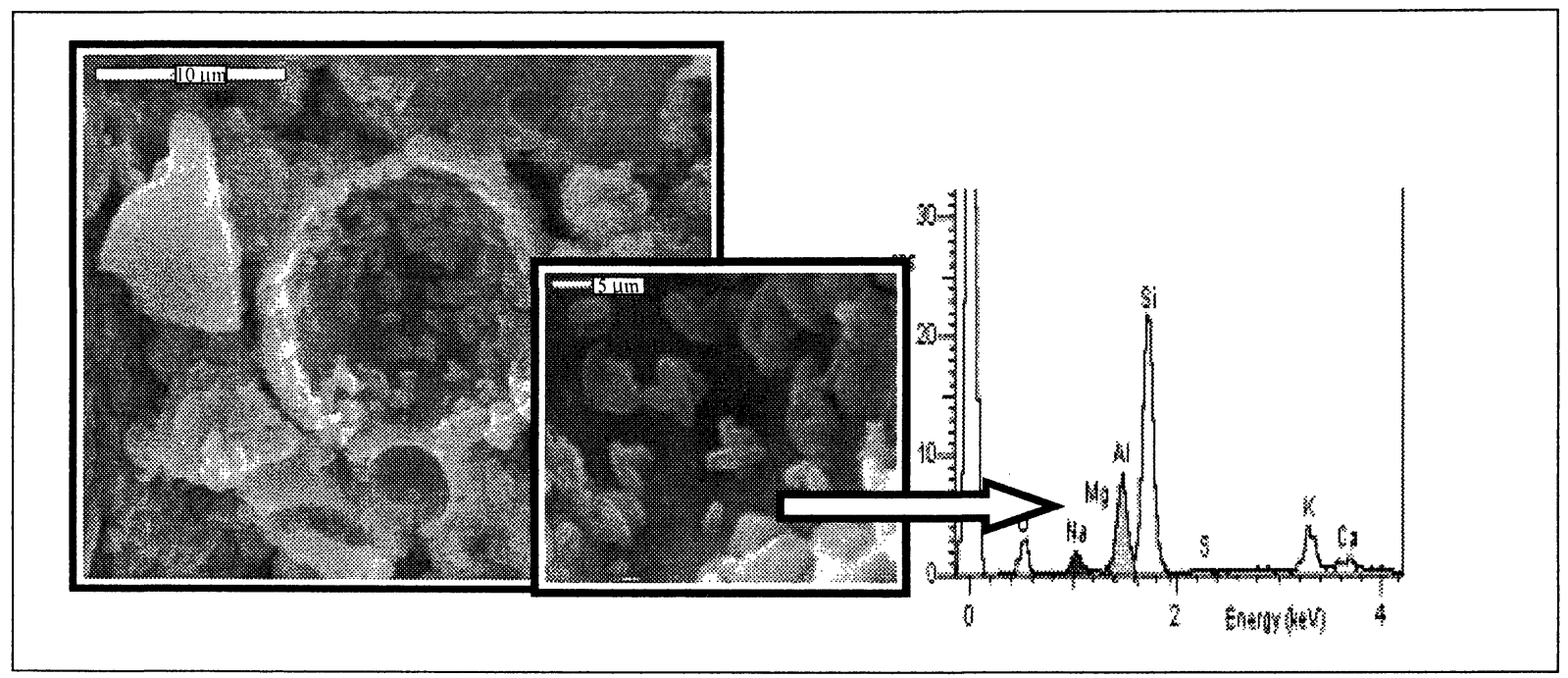

Figura 4.- Zeolitas cristalinas formadas en el sistema. Análisis elemental de los cristales de zeolitas.

Figure 4.- Crystalline zeolites developed in the system. Elemental analysis of zeolitic crystals. 
Si que el resto de la matriz (la relación $\mathrm{Si} / \mathrm{Al}$ de estos cristales es 2,35 y la relación $\mathrm{Si} / \mathrm{Al}$ del producto mayoritario de reacción es 1,9-2,0).

\section{c) $\mathrm{NaOH} \mathrm{10M(85 \% )} \mathrm{+} \mathrm{Waterglass}(15 \%)$}

I.a adición de una pequeña cantidad de waterglass $(15 \%)$ a la disolución activadora estimula la formación de microestructuras como la que se muestra en la Figura 5. En estas micrografías se puede observar la precipitación de un producto de reacción denso y compacto (más denso y compacto que el observado en los casos anteriores). Adicionalmente se observan algunos depósitos ricos en sílice $(\mathrm{Si} / \mathrm{Al}=2,7)$ aleatoriamente distribuidos en la matriz, y algunas microfisuras.

\section{d) $\mathrm{NaOH} 12.5 \mathrm{M}(15 \%)+$ Waterglass $(85 \%)$}

Cuando la cantidad de waterglass añadida al sistema aumenta hasta el $85 \%$ la morfología de la matriz sufre un cambio radical (Figura 6). El geopolímero formado en este caso parece un vidrio: ausencia casi total de poros y microestructura uniforme.

Este tipo de microestructura sólo se ve interrumpida por la presencia de partículas de ceniza que todavía no han reaccionado o por la presencia de huellas de esferas de ceniza y/o también por la presencia de microfisuras.
Si/Al ratio of these crystals is 2.35 whilst compared to a ratio of 1.9-2.0 in the main reaction product).

c) $10 \mathrm{M} \mathrm{NaOH} \mathrm{(85 \% )} \mathrm{+} \mathrm{Waterglass} \mathrm{(15 \% )}$

The addition of a small amount of waterglass (15\%) to the activating solution prompts the formation of microstructures such as shown in Figure 5. The precipitation of a dense and compact reaction product (denser and more compact than obsen'ed in the preceding cases) can be seen in these micrographs. Certain randomly distributed silica-rich deposits (Si) $A l=2.7)$ are also observed in the matrix, along with some microcracking.

\section{d) $12.5 \mathrm{M} \mathrm{NaOH}(15 \%)+$ Waterglass (85\%)}

When the amount of waterglass added to the system is raised to $85 \%$, matrix morphology undergoes a radical change (Figure 6). The geopolymer formed in this case is similar to glass, i.e., with a near absence of pores and a uniform microstructure.

The only discontinuities in this microstructure are ash particles that have not yet reacted, the empty shells of former ash spheres and/or microcracks.

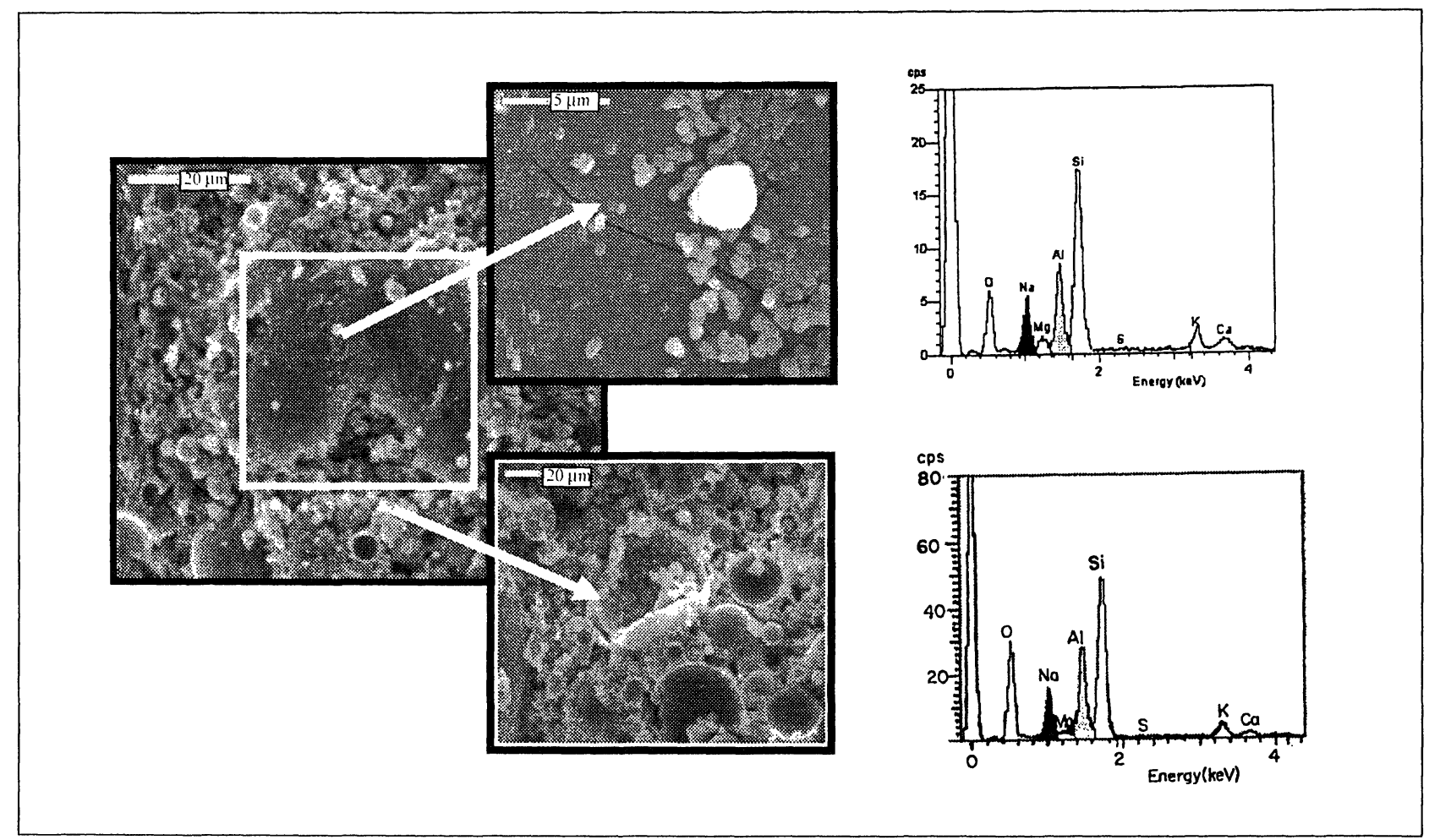

Figura 5.- Aspecto general de la microestructura de la ceniza volante activada con $\mathrm{NaOH}(85 \%)+$ waterglass (15\%). Detalle y análisis elemental de las diferentes zonas de la microestructura.

Figure 5. - (iencral aspect of the microstructure of fly ashes activated with $\mathrm{Na}) \mathrm{H}(8.5 \%)$ waterglass $(1.5 \%)$. Details and elemental analvsis of the different areas of the microstruchure. 


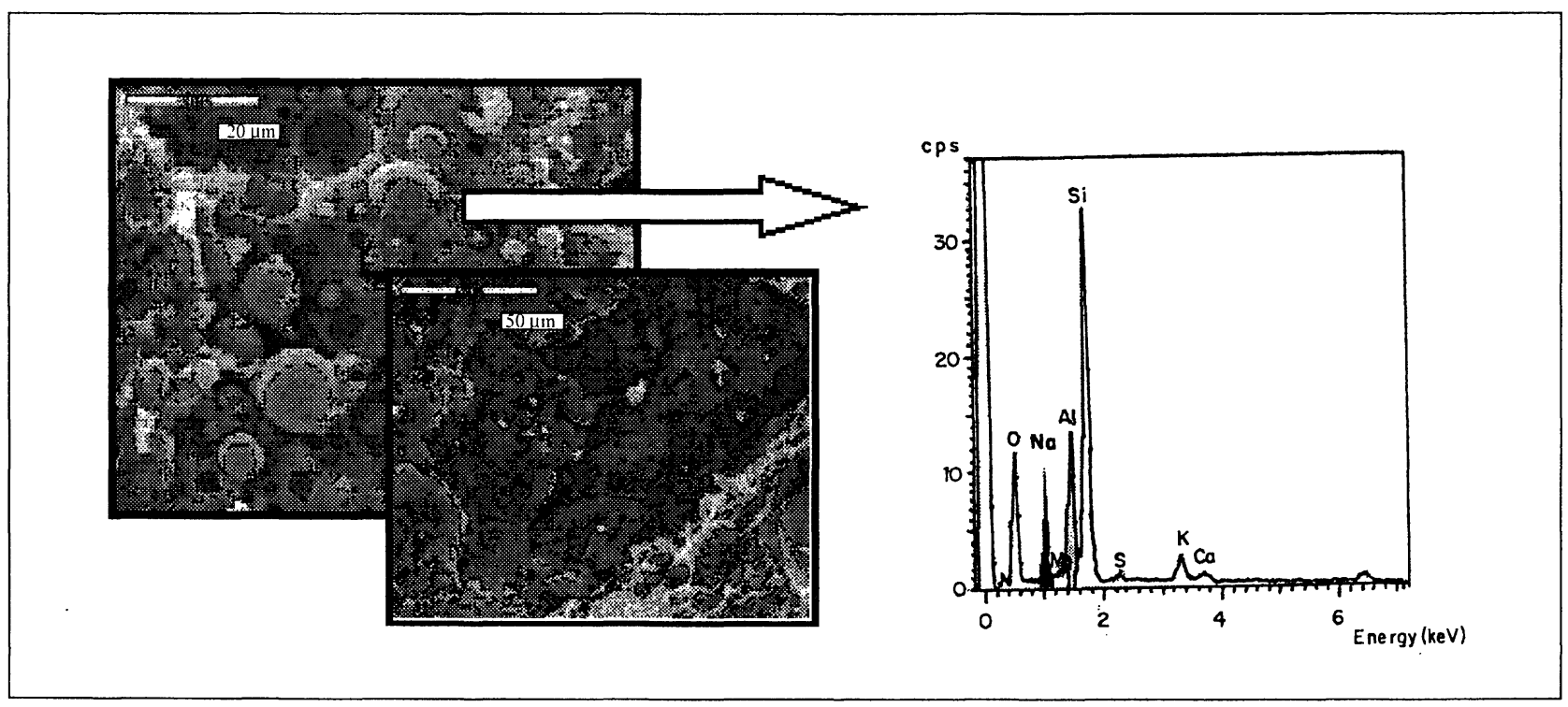

Figura 6.- Aspecto general de la microestructura de la ceniza volante activada con la disolución de $\mathrm{NaOH}(15 \%)+$ waterglass $(85 \%)$. Detalle y análisis elemental del producto de reacción vitreo.

Figure 6.- General aspect of the microstructure of fly ashes activated with a dissolution of NaOH (15\%) + waterglass (85\%). Details and elemental analysis of the glassy reaction product.

Se considera que estas microfisuras son el resultado de un conjunto de tensiones internas que se producen en el material durante el desarrollo microestructural y que el sistema no puede absorber dada la escasez de poros en el mismo.

El contenido de Si y Na de esta matriz es superior al del resto de los geopolímeros estudiados $(\mathrm{Si} / \mathrm{Al}=2,5-2,8$ y $\mathrm{Na} / \mathrm{Al}=1,5-1,6)$.

\subsection{Efecto de la concentración del activador}

La siguiente variable de trabajo que fue tomada en consideración en el presente estudio fue la concentración del activador. Esta variable ha demostrado jugar un papel extremadamente importante a la hora de diseñar la dosificación de un mortero $u$ hormigón de ceniza activada. Las Figuras 7 y 8 ilustran claramente las modificaciones microestructurales que se pueden inducir en el producto final de reacción como consecuencia de la variación de la concentración de álcalis en el sistema.

Ambas micrografías muestran los cambios concretos que tienen lugar en el producto de reacción al incrementar la concentración de la disolución activadora (disolución de $\mathrm{KOH}$ ) desde $8 \mathrm{M}$ a $18 \mathrm{M}$.

Dichos cambios consisten básicamente en un incremento de la densidad de la matriz y en la formación de un material quasi-vítreo (similar al obtenido con activadores preparados a partir de mezclas de hidróxido sódico y waterglass) a medida que la concentración del activador aumenta.
Microcracks, in turn, are regarded to be the result of a series of internal stresses arising in the material as the microstructure develops, which the system is unable to absorb for the sparsity of pores.

This matrix has higher Si and Na contents than any of the other geopolymers studied ( $\mathrm{Si} / \mathrm{Al}=2.5-2.8$ and $\mathrm{Na}$ / $A l=1.5-1.6)$.

\subsection{Impact of activator concentration}

The next working variable taken into account in this study was activator concentration. This parameter has proved to play an extremely important role in designing the dosage in ash-activated mortar and concrete. Figures 7 and 8 clearly illustrate the microstructural modifications that can be induced in the final reaction product by varying the alkali concentration in the system.

These micrographs depict the specific changes taking place in the reaction product when the concentration of the activating solution ( $\mathrm{KOH}$ solution) is raised from $8 M$ to $18 M$. These changes consist essentially in a rise in matrix density and the formation of a quasi-glassy material (similar to the product obtained with sodium hydroxide + waterglass activators), as the activator concentration increases. 


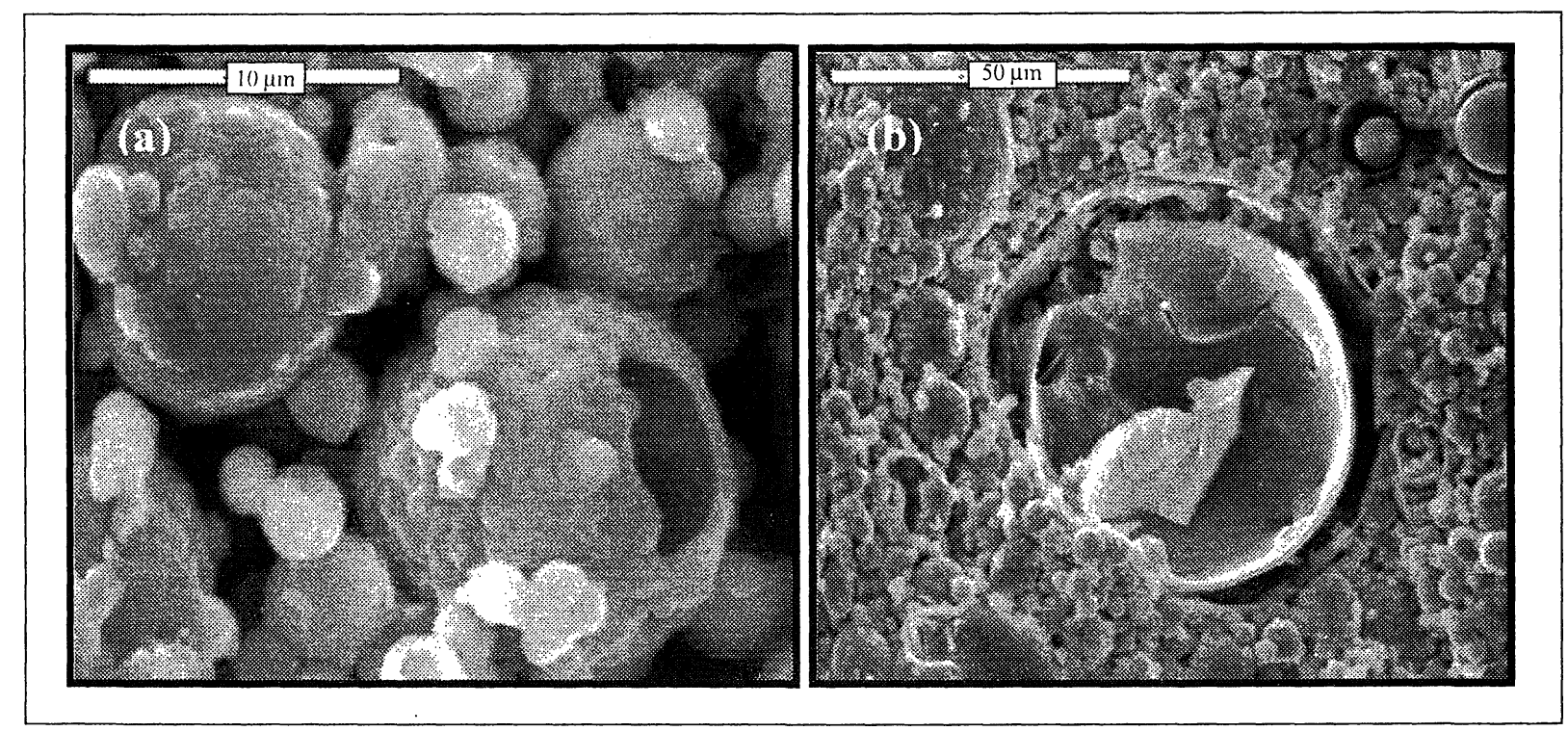

Figura 7.- (a) Ceniza volante activada con $\mathrm{KOH}(8 \mathrm{M})$; (b) ceniza volante activada con $\mathrm{KOH}(18 \mathrm{M})$.

Figure 7.- (a) $\mathrm{KOH}$ (SM) activated fly ash: (b) $\mathrm{KOH}$ (lSM)-activated fly ash.

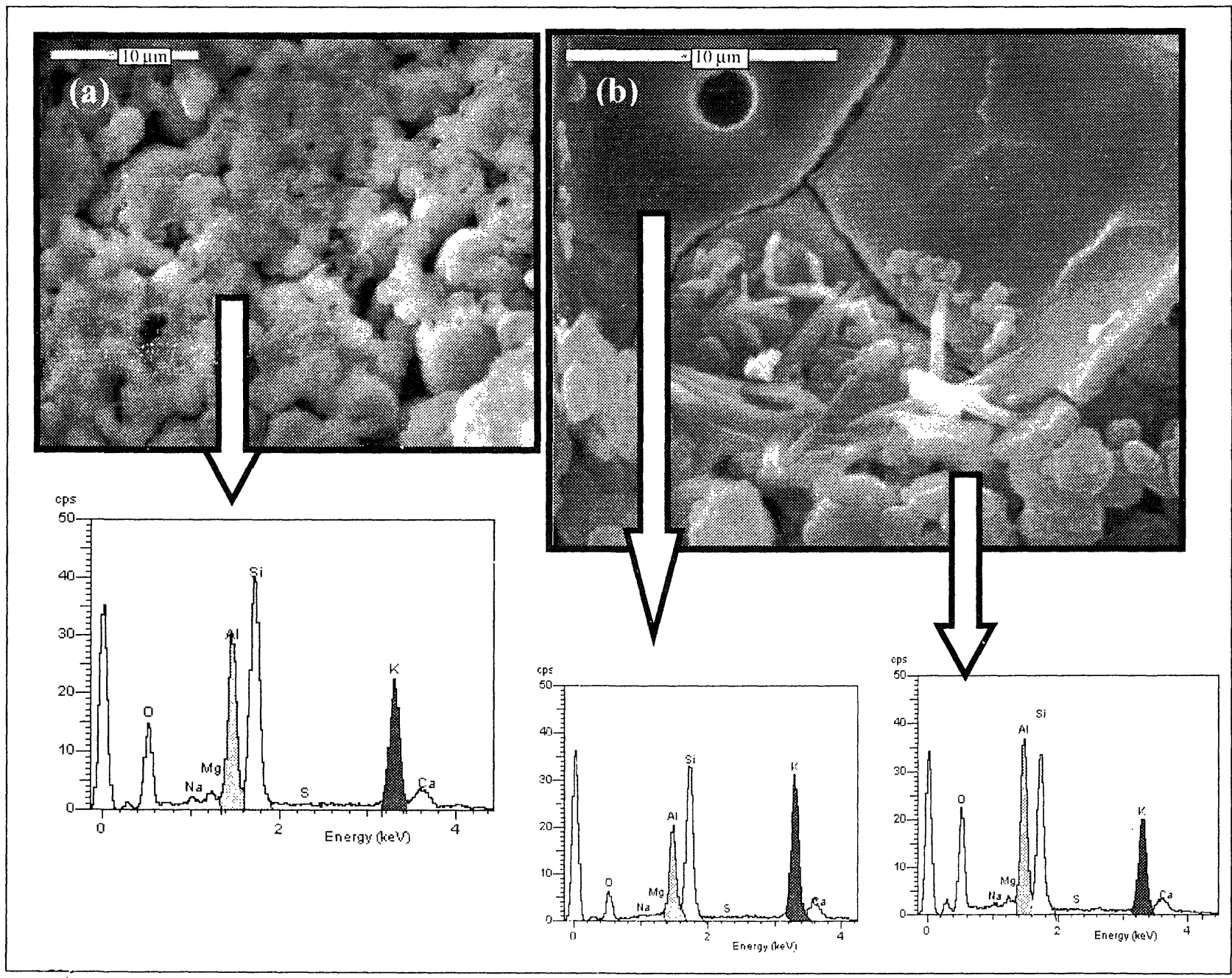

Figura 8.- (a) Ceniza activada con $\mathrm{KOH}(8 \mathrm{M})$ : (b) ceniza activa con $\mathrm{KOH}(18 \mathrm{M}$ ). Detalle de los productos de reacción y análisis elemental. Figure \&.- (a) $\mathrm{K}(\mathrm{H}$ (8M) activated fly ash: (h) $\mathrm{KOH}(18 \mathrm{M})$-activated fly ash. Details of the reaction products and elemental analvsis. 
La Figura 8 (b) nos muestra este estado quasi-vítreo del producto de reacción generado en dicho medio altamente alcalino. También en la micrografia se pueden observar algunas microfisuras. De hecho, las microfisuras se pueden considerar como una característica particular de este tipo de microestructuras. Además también se observa la presencia de una serie de cristales con forma de aguja que probablemente corresponden a la mullita de la ceniza original que ha sido parcialmente atacada (14).

Finalmente, otra interesante conclusión extraída del estudio microanalítico de estas dos muestras de "geopolímero" (ver Figura 8) es que la cantidad de K fijada en la matriz (b) es mayor que la cantidad de $\mathrm{K}$ fijada en la matriz (a). La relación $\mathrm{K} / \mathrm{Al}$ es de 1,4-1,5 en el caso de activar con $\mathrm{KOH} 18 \mathrm{M}$, y de $0,8-0,9$ para el caso de la activación con la disolución $8 \mathrm{M}$.

\subsection{Efecto del envejecimiento del material}

En la Figura 9 se comparan unas microestructuras correspondientes a una ceniza recientemente activada con una disolución $8 \mathrm{M}$ de $\mathrm{NaOH}$ y térmicamente curada durante $5 \mathrm{~h}$ a $85^{\circ} \mathrm{C}$ con la misma muestra 5 años más tarde (la muestra se mantuvo durante todo ese tiempo en condiciones de temperatura y humedad ambiente).

El resultado del envejecimiento de este material es esencialmente la compactación del sistema y el aumento
Figure 8(b) illustrates the quasi-glassy state of the reaction product generated in such a highly alkaline environment. Several microcracks can also be observed. Indeed, microcracks can be regarded to be a characteristic specific to this type of microstructures. $A$ series of needle-shaped crystals can also be identified, which more than likely correspond to the partial attack of the mullite that was present in the original ash, as seen in the picture (14).

Finally, another interesting conclusion to be drawn from the microanalytic study of these two "geopolymer"samples (see Figure 8) is that the amount of potassium fixed by matrix (b) is greater than the amount fixed by matrix (a). The K/Al ratio is 1.4-1.5 when the ash is activated with $18 M \mathrm{KOH}$ and 0.8-0.9 when the concentration of the solution is $8 M$.

\subsection{Impact of material ageing}

Figure 9 compares the microstructure of an $8 \mathrm{M} \mathrm{NaOH}$ activated ash shortly after oven-drying for $5 \mathrm{~h}$ at $85^{\circ} \mathrm{C}$ to the microstructure of the same sample five years later (the sample was stored at room temperature and humidity in the interim).

The impact of material ageing is primarily system compaction and an increase in the amount of sodium

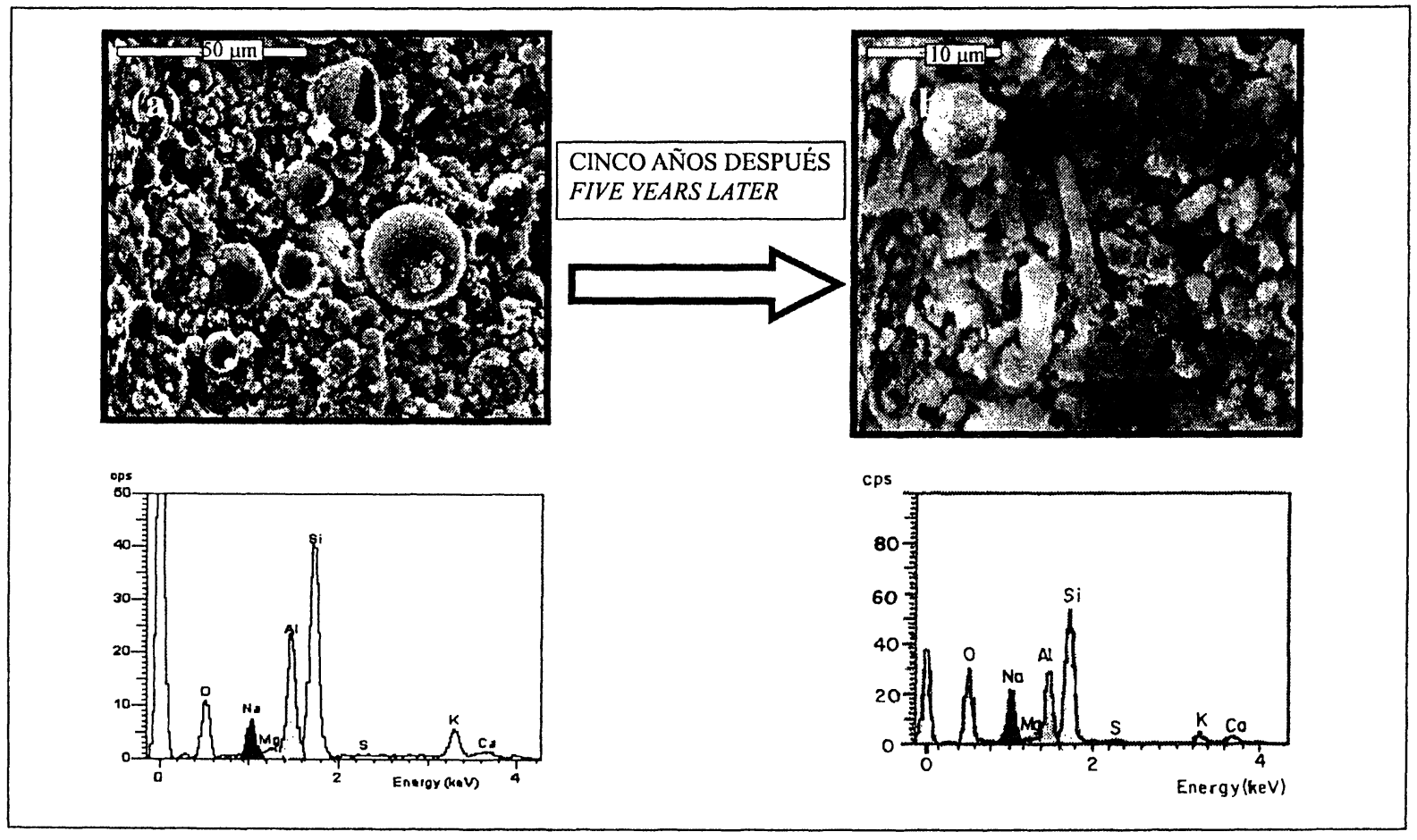

Figura 9.- (a) Ceniza volante activada con $\mathrm{NaOH}(8 \mathrm{M})$ (curada 5 horas a $85^{\circ} \mathrm{C}$ ); (b) la misma muestra 5 años después.

Figure 9.- (a) $\mathrm{NaOH}(8 \mathrm{M})$ activated fly ash (cured 5 hours at $85^{\circ} \mathrm{C}$ ); (b) Same sample 5 years later. 
de la cantidad de sodio fijado por los productos de reacción. En las Figuras 10 y 11 se puede ver el efecto del envejecimiento de una matriz de "geopolímero" obtenido con ceniza volante activada con una disolución $8 \mathrm{M}$ de $\mathrm{KOH}$ durante $5 \mathrm{~h}$ a $85^{\circ} \mathrm{C}$.

Un detalle importante a destacar esta relacionado con la composición de los productos de reacción 5 años después de la preparación del material: estos productos se han hecho más ricos en silito y potasio con el paso fixed by the reaction products. Figures 10 and 11 show the effect of ageing on a "geopolymer" matrix obtained with $8 \mathrm{M} \mathrm{NaOH-activated} \mathrm{fly} \mathrm{ash} \mathrm{oven-dried} \mathrm{for} 5 \mathrm{~h}$ at $85^{\circ} \mathrm{C}$.

One relevant fact to be stressed in connection with reaction product composition five years after the material was prepared is that the silicon and potassium content in these products grows over time. Moreover;

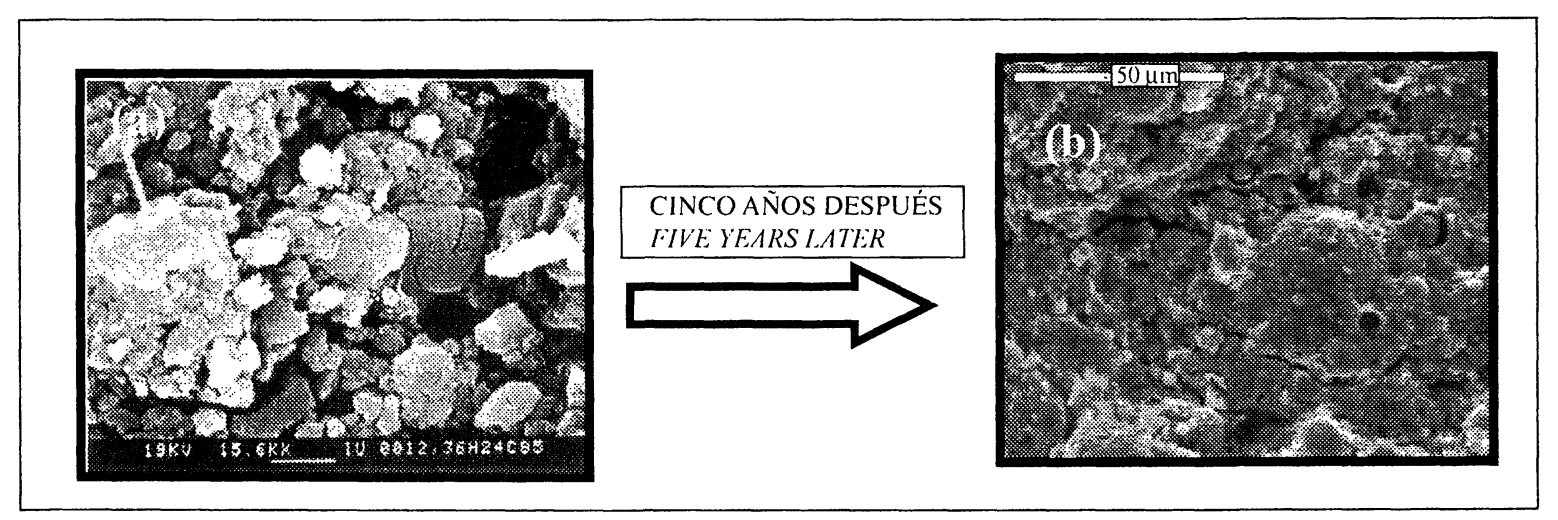

Figura 10.- Ceniza volante activada con $\mathrm{KOH} 8 \mathrm{M}$ (curada 5horas a $85^{\circ} \mathrm{C}$ ); (b) la misma muestra 5 años después. Figure 10.- (a) KOH (8M) activated fly ash (cured 5 hours at $85^{\circ} \mathrm{C}^{\circ}$ ): (b) Same sample 5 years later:

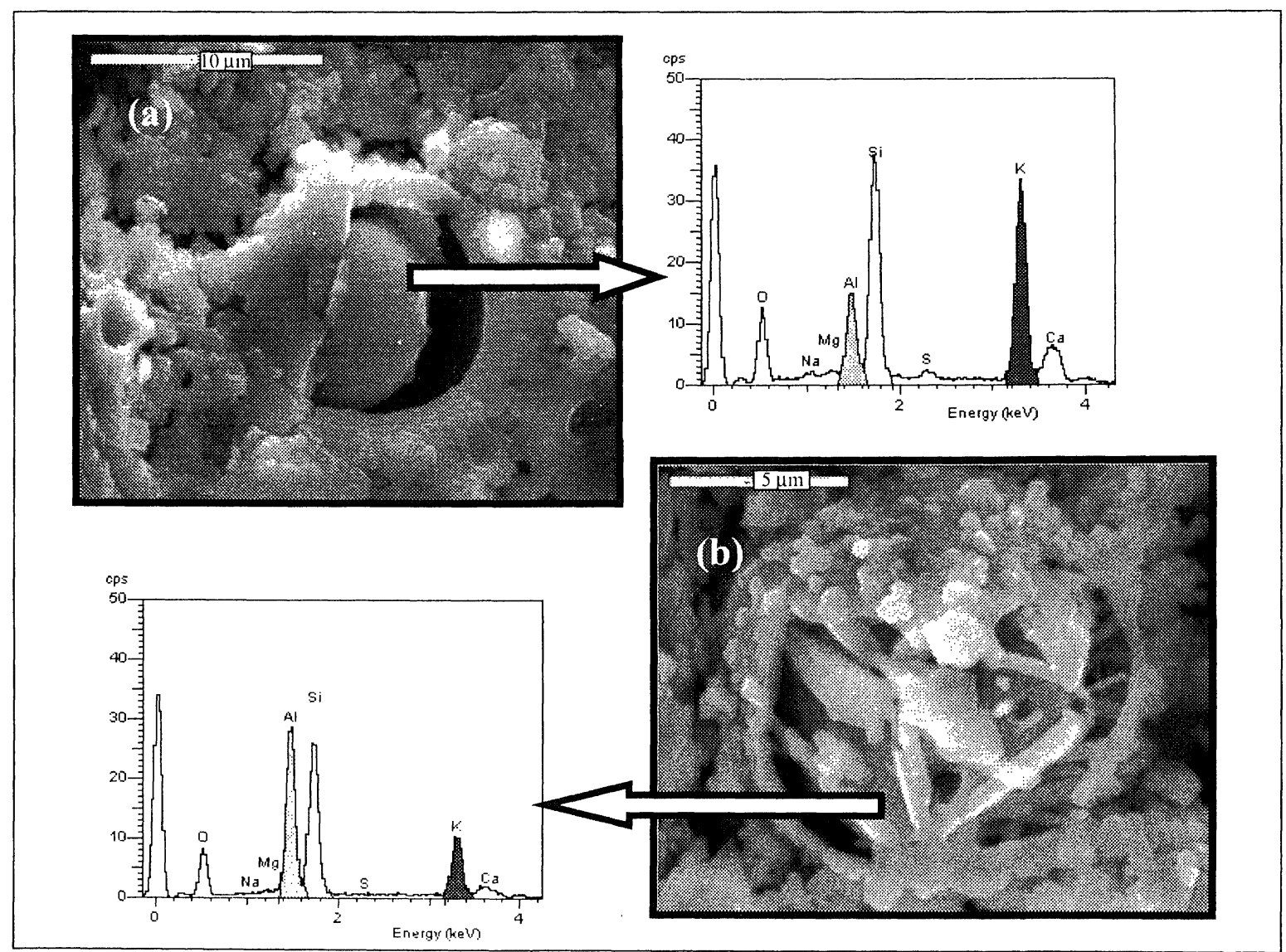

Figura 11.- Análisis elemental de la muestra envejecimiento durante 5 años: (a) principal producto de reacción: (b) Mullita atacada. Figure 11.- Lileme'ntal analusis of s. vears aged sample: (a) Main reaction product: (b) Attacked Mullite. 
del tiempo. Además la presencia de pequeños cristales con forma de aguja y ricos en aluminio, asociados a una mullita parcialmente atacada, es característica de este tipo de sistemas envejecidos.

Finalmente, en las Figuras 12 y 13 se muestra el efecto del envejecimiento de una matriz de geopolímero basado en la activación de una ceniza, 5 años después de haber sido activada con una disolución alcalina con un alto contenido en waterglass.

No se detectan cambios morfológicos significativos como consecuencia del paso del tiempo, sin embargo el "geopolímero", "viejo" ha incrementado su contenido en silicio y sodio. the presence of small aluminium-rich, acicular crystals corresponding to partially attacked mullite is characteristic of ageing systems.

Finally, Figures 12 and 13 show the effect of ageing on an activated ash five years after activation with an alkaline solution with a higher waterglass content.

No significant morphological changes are detected over time, although the "older" "geopolymer" has a higher silicon and sodium content.

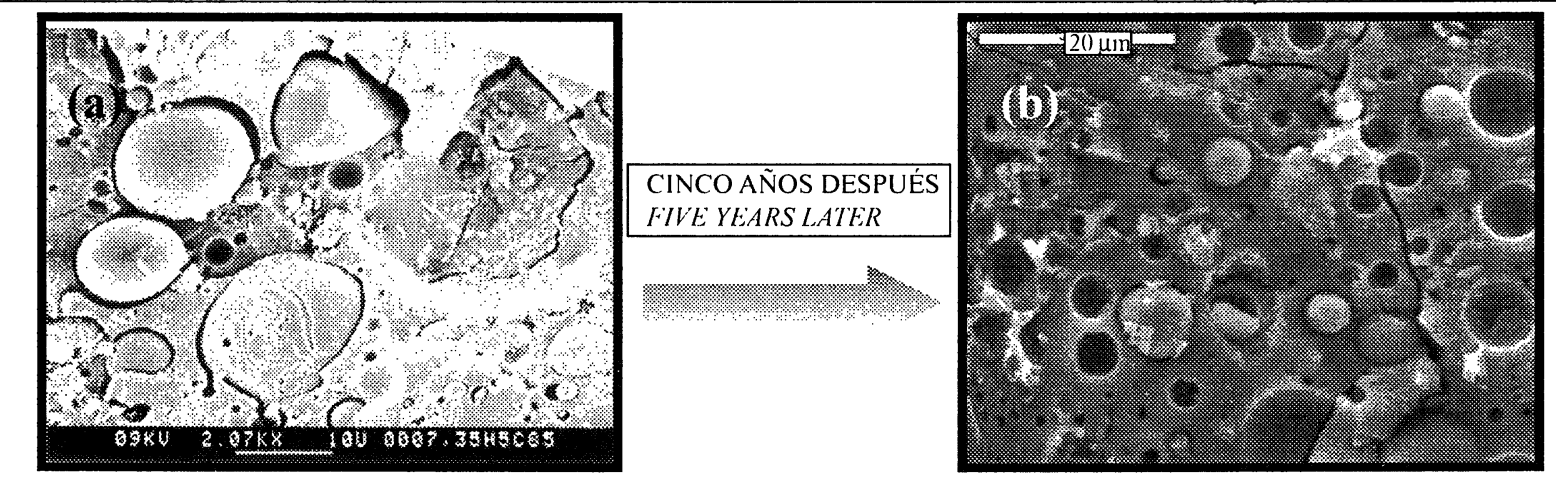

Figura 12.- Ceniza volante activada con Waterglass $(85 \%)+\mathrm{NaOH}$ en lentejas (15\%), (a) curada 5 horas a $85{ }^{\circ} \mathrm{C}$ (b) 5 años después. Figure 12.- activated fly ash with waterglass $(85 \%)+\mathrm{NaOH}$ pellets (15\%) (a) cured 5 hours at $85{ }^{\circ} \mathrm{C}$; (b) same sample 5 years later:

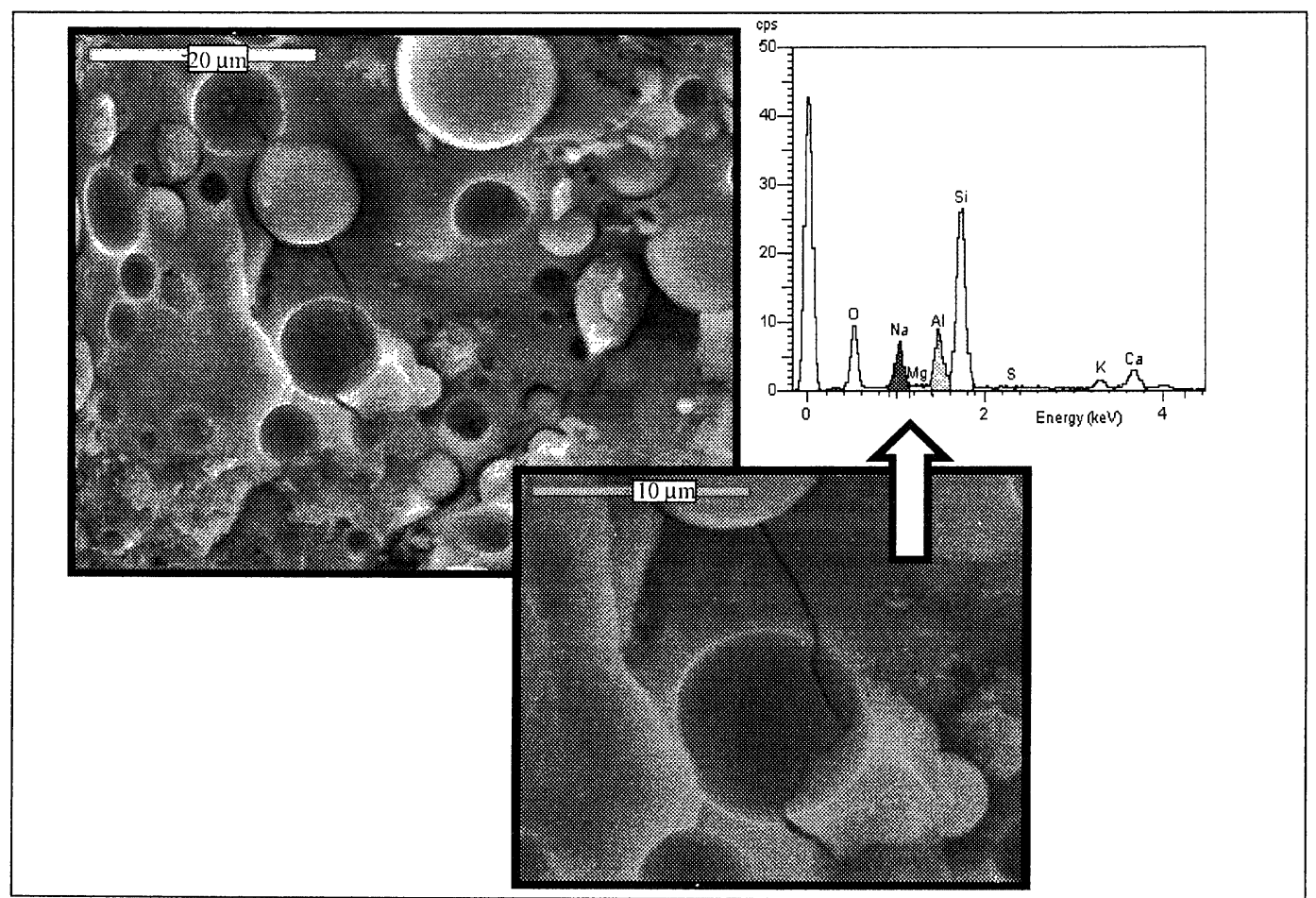

Figura 13.- Detalle de la microestructura de este material. Microfisuras. Análisis elemental de los productos de reacción, relación $\mathrm{Si} / \mathrm{Al}=3,5-3,6$ y $\mathrm{Na} / \mathrm{Al}$ ratio $=2,(0)-2,2$

Figure 13.- Detail of the microstructure of this material. Microcracks. Elemental analysis of the reaction product: Si/Al ratio $=3.5-3.6$ and Na/ Al ratio $=2 .(1)-2,2$ 
Un hecho muy importante a tener en cuenta en opinión de los autores es la ausencia de carbonatos en estas muestras envejecidas, almacenadas en el laboratorio en condiciones de temperatura $\mathrm{u}$ humedad ambiente durante 5 años. La ausencia de carbonatos se piensa que esta estrechamente relacionada con el aparente incremento de compacidad del sistema. El sistema permanece suficientemente impermeable como para prevenir o reducir los procesos de carbonatación.

\subsection{Efecto de la naturaleza de los materiales de partida}

El ultimo punto de esta investigación está relacionado con el estudio del efecto de la naturaleza de los materiales de partida sobre la microestructura de los geopolímeros preparados. La totalidad de la investigación previamente descrita se llevo a cabo usando una ceniza volante como principal material de trabajo, sin embargo algunos autores trabajan con metacaolin para sintetizar los "geopolímeros".

En este sentido, pensamos que la peculiar morfología de las cenizas volantes hacen de éstas un material muy útil para el estudio de la microestructura de los sistemas "geopoliméricos". A lo largo de este proceso se ha demostrado claramente que, por medio de la microscopia electrónica, es fácil distinguir entre las partículas originales de ceniza y el principal producto de reacción ("geopolímero") o entre dichas partículas esféricas y otros compuestos minoritarios, tales como las zeolitas cristalinas, la mullita, etc.

Sin embargo, cuando se usa metacaolín como principal material de trabajo este tipo de investigación microestructural se hace mucho más difícil. Como se puede observar en las Figuras 14 (a) y 14 (b) es casi imposible distinguir el metacaolín original del "geopolímero" formado durante la activación alcalina.
Attention is drawn to another fact that the authors regard to be very important, namely the lack of carbonates in these older samples, stored in the laboratory at room temperature and humidity for five years. The absence of carbonates is thought to be closely related to the apparent increase in system compactness, which would afford it sufficient impermeability to prevent or reduce carbonation.

\subsection{Impact of the nature of the initial materials}

The final question addressed in this research deals with the study of the effect of the nature of the original materials on the microstructure of the polymers prepared. All the foregoing trials were conducted using fly ash as the main prime material, even though other authors work with metakaolin to synthesise "geopolymers".

In this regard we feel that the peculiar morphology of fly ash makes it especially suitable for studying "geopolymer"system microstructure. It has been repeatedly shown throughout this paper that the original ash particles can be readily distinguished from the main ("geopolymer") reaction product or from other minority compounds such as crystalline zeolite, mullite, etc., under the electron microscope.

This type of microstructural studies are more difficult when metakaolin is used as the main prime material, however. As Figures 14 (a) and 14 (b) show, it is nearly impossible to distinguish the original metakaolin from the "geopolymer"formed during alkali activation. In another vein, the zeolite crystals found in metakaolin

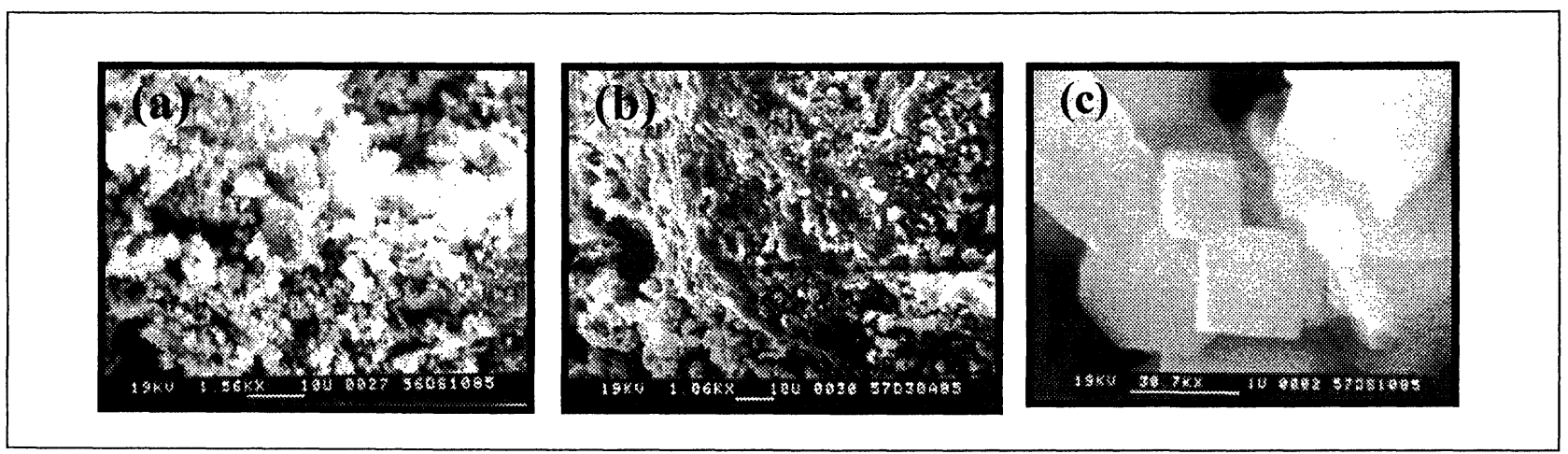

Figura 14.- (a) Metacaolin activado con una disolución de $\mathrm{NaOH} 8 \mathrm{M}$ (curado 10 días a 85 " $\mathrm{C}$; (b) Metakaolin activado con una disolución de $\mathrm{KOH}$ $18 \mathrm{M}$ (curado 30 dias a $85^{\circ} \mathrm{C}$ ); (c) cristales de zeolita Linde detectados en el metacaolin activado

Figure 14.- (a) Actirated Metakaolin with an $8 \mathrm{M} \mathrm{NaOH}$ dissolution (curing 10) days at 85 "C): (b) Activated Metakaolin with an I8M KOH dissolution (curing 30 davs at 85 " $\mathrm{C})$ : (c) Linde crvstals detected in activated Metakaolin. 
Además debería destacarse que los cristales zeoliticos encontrados en el caso de la activación del metacaolín (productos minoritarios de reacción), son, a veces, muy distintos de los encontrados en el caso de las cenizas activadas. En la micrografía 14 (c) se pueden observar algunos cristales cúbicos, muy bien formados, de una zeolita llamada Linde.

\section{DISCUSIÓN Y CONCLUSIONES}

Las micrografías de las Figuras 2 a 6 demuestran que cualquiera que sea el activador usado, una fracción sustancial de las microesferas que conforman el producto original se transforma en un compuesto compacto y básicamente amorfo que ocupa la mayor parte del volumen sólido del nuevo material. No obstante, las microestructuras varían dependiendo del tipo de activador utilizado. Así por ejemplo, el producto generado en la disolución de $\mathrm{NaOH}$ contiene un número relativamente grande de poros. Sin embargo, la incorporación de una pequeña cantidad de waterglass $(15 \%)$ a la disolución activadora conlleva la obtención de una microestructura más densa y más compacta. Esta compactación está probablemente relacionada con un incremento del grado de polimerización del geopolímero, hecho que se deduce del incremento de la relación $\mathrm{Si} / \mathrm{Al}$, desde 1,9-2,0 hasta 2,5-2,7.

Un incremento sustancial de la cantidad de waterglass incorporada al sistema es responsable de la apariencia microscópica que adquiere este y que se puede observar en la Figura 6: casi ausencia total de poros (igual que muchos vidrios) y presencia de algunas microfisuras producidas por tensiones internas que se desarrollan en el material durante la formación de la microestructura.

Cuando la naturaleza del activador cambia (empleo de $\mathrm{KOH}$ en lugar de $\mathrm{NaOH}$ ) la microestructura del material resultante se modifica radicalmente. La potasa ataca al componente vítreo de la ceniza tal y como era de esperar, pero los productos de reacción permanecen adheridos a las partículas esféricas originales sin que se produzca la dispersión de éstos por todo el sistema, dejando, por lo tanto, una gran cantidad de huecos vacíos en la matriz. Además, en este caso, la relación $\mathrm{Si} / \mathrm{Al}$ del producto de reacción es aproximadamente $1,7-1,8$, ligeramente inferior a la relación encontrada en el caso de la activación con sosa. De todos estos hechos se podría deducir que el potasio es un activador menos enérgico o más lento que el sodio.

Si la variable objeto de discusión es la concentración del activador (concentración de álcalis en el sistema de reacción), entonces se debería señalar el siguiente efecto fundamental sobre la microestructura del producto de reacción: incremento del contenido de activation (minority reaction products) sometimes differ widely from the crystals formed in activated fly ash. A few very well formed cubic crystals corresponding to a zeolite known as Linde can be seen in micrograph 14 (c).

\section{DISCUSSION AND CONCLUSIONS}

The micrographs in Figures 2 to 6 show that regardless of the activator used, a substantial fraction of the microspheres that comprise the original powder are transformed into a compact, essentially amorphous and tightly bound compound that occupies much of the solid volume of the new material. Nonetheless, the microstructure varies depending on the type of activator used. Thus, for instance, the product generated when the NaOH solution is used contains a relatively large number of pores. And yet the inclusion of a small amount of waterglass (15\%) in the activating solution vields a denser and more compact microstructure. This compaction is very likely related to enhanced polymerisation of the geopolymer, as may be inferred from the rise in the Si/Al ratio from 1.9-2.0 to 2.5-2.7.

When the reaction product ensuing from ash activation with substantial amounts of waterglass in the system is viewed under the microscope, the result is as can be observed in Figure 6: a near absence of pores (as in many types of glass) and presence of tiny microcracks produced by internal stresses arising in the material during microstructure formation.

A change in the nature of the activator (use of $\mathrm{KOH}$ instead of $\mathrm{NaOH}$ ) leads to a radical change in the microstructure of the resulting material. Potash attacks the glassy component of the ash, as might be expected, but the reaction products bind to the original spherical particles, and do not, therefore, spread throughout the system. This means that a large number of voids in the matrix remain empty. Moreover, in this case the Si/Al ratio of the reaction product is approximately 1.7-1.8, or slightly lower than the ratio found when sodium hydroxide is used as the activator. It may be deduced from the foregoing that potash is a less powerful or at least a slower activator than sodium.

When the variable considered is activator concentration (alkali concentration in the reaction system), the most salient effect on the microstructure of the reaction product is an increase in the alkali content fixed by the "geopolymer" at higher concentrations of 
álcali fijado por el "geopolímero" a medida que aumenta la concentración de álcalis en la disolución activadora. Esta observación podría explicar la evolución microestructural del material hacia un estado quasi-vítreo.

Finalmente, el proceso de envejecimiento de los "geopolimeros" basados en cenizas parece tener un conjunto de consecuencias que son independientes del "geopolímero" estudiado:

- Incremento de la compacidad de la matriz

- Incremento del contenido de silicio y álcali en el principal producto de reacción

- Ausencia de carbonatos

En este contexto el estudio microscópico de una serie de muestras de ceniza volante activada bajo diferentes condiciones experimentales, junto con el estudio microscópico de algunos sistemas basados en metacaolín han permitido concluir definitivamente que los "geopolímeros" constituyen una familia de materiales con una base química común, pero con diferentes posibles microestructuras.

\section{AGRADECIMIENTOS}

A la Dirección General de Investigación Científica del MCYT por la financiación del proyecto COO-1999AX-038. Al Gobierno de la Comunidad de Madrid por la beca postdoctoral asociada a esta investigación. Y, finalmente, a J. M. Llueca, por su colaboración en el trabajo de microscopía. alkali in the activating solution. This finding may explain the microstructural evolution of the material to a quasi-glassy state.

Finally, the ageing of "geopolymers" made from fly ash appears to have a series of consequences common to all polymers:

\section{- Increase in matrix compactness \\ - Increase in the silicon and alkali content in the main reaction product \\ - Absence of carbonates}

In this context the microscopic study of a series of fly ash samples activated under different experimental conditions, together with the microscopic study of a number of metakaolin-based systems, leads to the definitive conclusion that "geopolymers" are a family of materials with one and the same basic chemical composition but potentially different microstructures.

\section{ACKNOWLEDGEMENTS}

Project COO-1999-AX-038 was financed by the Ministry of Science and Technology's Directorate General of Scientific Research. The Regional Government of Madrid sponsored a post-doctoral grant associated with this research. Finally, thanks are owed to J.M. Llueca for his co-operation in connection with the microscopic survey.

\section{BIBLIOGRAFÍA}

(1) A. Fernández-Jiménez, F. Pucrtas: "Cementos de escorias activados alcalinamente. Determinación del grado de reacción”. Mater Construcc. Vol. 51, N²61, pp. 53-65 (2001).

(2) A. Fernández-Jiménez, F. Puertas: "Influencia de la concentración del activador sobre la cinética del proceso de activación alcalina de una escoria de alto horno". Mater Construcc. Vol. 47, № 246, pp.31-42 (1997).

(3) F. Puertas, R. de Gutiérrez, A. Fernández-Jiménez, S. Delvasto, J. Maldonado: "Morteros de cementos alcalinos. Resistencia química al ataque por sulfatos y agua de mar". Mater Construcc. Vol. 52, No 267, pp. 55-71 (2002)

(4) A. Fernández-Jiménez, E. E. Lachowski, A. Palomo, D. E. Macphee: "Microstructural characterisation of alkali-activated cement matrices for waste immobilization". Cem. Concr. Comp. (accepted for publication). (In press, 2003).

(5) I. Janotka, S. C. Mojumdar: "Hidratación y resistencias al ataque por sulfatos de cementos portland y cementos con zeolitas naturales". Mater Construcc. Vol. 53, N²69, pp. 17-27 (2003).

(6) A. Palomo, M. W. Grutzeck, M.T. Blanco: “Alkali-activated fly ashes. A cement for the future". Cem. Concr. Res., 29, pp.13231329 (1999).

(7) W. Lee, J. Van Deventer.: "Factors affecting the setting behaviour of fly ash based geopolymeric binders". Geopolymers 2002 , Melbourne (2002).

(8) A. Fernández-Jiménez, A. Palomo: "Characterisation of fly ashes in function of its potential alkali activation properties" Fuel. Vol 82, pp 2259-2265 (2003).

(9) F. F. V. Barbosa, J. D. K. MacKenzie, C. Thaumaturgo: "Synthesis and characterisation of materials based on inorganic polymers of alumina and silica: sodium polysialate polymers". Int. J. of Inorganic Materials, 2, pp.309-317 (2000).

[10] P. Krivenko, M. Mokhort and O. Petropavlovskii "Industrial uses of geocement-based materials in construction" Geopolymers 2002. Melbourne (Australia). 15p (2002). 
(11) A. Palomo, S. Alonso, A. Fernández-Jiménez, I. Sobrados, J. Sanz: "Alkaline activation of fly ashes. A NMR study of the reaction products". J. Am. Ceramic. Soc. (accepted for publication, 2004).

(12) J. S. Van Deventer, L.Xu, G. Luckey: "Processing, microstructure and properties of fly ash based geopolymers". 105 ${ }^{\text {th }}$ annual meeting of the Am. Ceram. Soc., Nashville (TN), (2003).

(13) M. Criado, A. Fernández-Jiménez, A. Palomo: “Alakali activ'ated fly ashes. Effect of the curing procedure on the characteristics of the final product". Cem. Concr. Res. (submitted for publication).

(14) G. Steenbrugen, G. G. Hollman: "The synthesis of zeolites from fly ash and the properties of the zeolite products". J. Geochem. Explor. Vol. 62, pp. 305-309 (1998). 


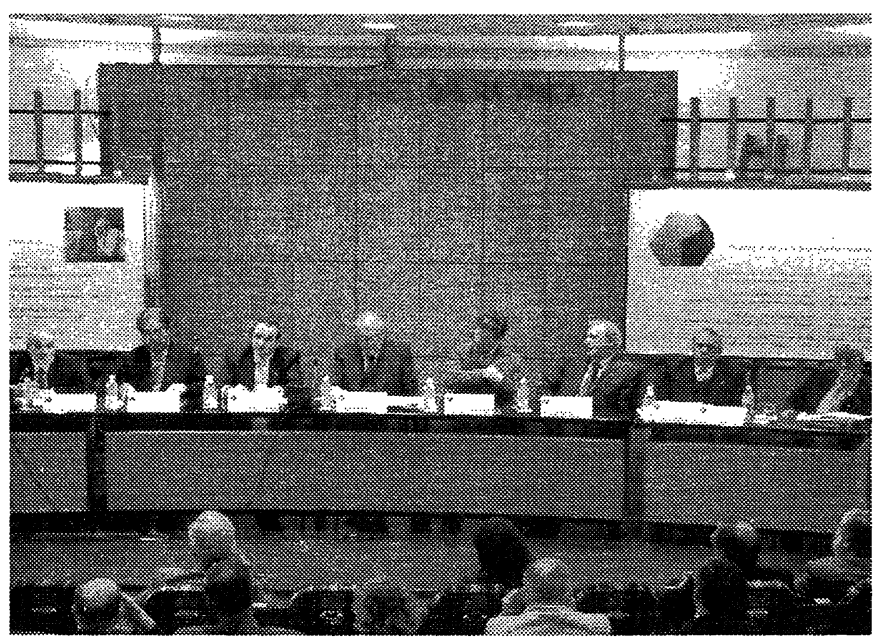

Acto de presentación de la Fundación Eduardo Torroja.

\section{FUNDACIÓN EDUARDO TORROJA}

El pasado día 30 de marzo tuvo lugar el Acto de constitución y presentación de la Fundación Eduardo Torroja en el Instituto de Ciencias de la Construcción Eduardo Torroja (CSIC). C/ Serrano Galvache n" 4, Madrid.

Al Acto asistió el Presidente del Consejo Superior de Investigaciones Cientificas D. Emilio Lora-Tamayo.

La apertura del acto, corrió a cargo del presidente de la Fundación, D. Leopoldo Calvo Sotelo. Tras él intervinieron D. Emilio Lora-Tamayo, el secretario de la Fundación, D. Antonio Sáez de Miera y el presidente de la Asociación de Miembros del Instituto Eduardo Torroja, D. José Antonio Torroja Cavanilles.

\section{Los Objetivos Fundacionales}

- Difundir entre la sociedad española la evolución histórica, la situación actual y las nuevas tendencias de la construcción, destacando el liderazgo de este sector en el desarrollo de la economía y del bienestar social valorando los beneficios que la misma comporta para la mejora y mantenimiento de nuestro patrimonio cultural.

- Promover el desarrollo de actividades relativas a la arquitectura y a la ingeniería civil como vehículo de potenciación mutua, identificando y promoviendo temas de investigación en los campos de la ingeniería civil y la arquitectura, todo ello de forma integradora y multidisciplinar, apoyándose en el ejemplo y la figura de Eduardo Torroja.

- Realizar con carácter prioritario la actualización, catalogación, mantenimiento y difusión del inventario de todos los documentos que componen el legado cientifico y técnico del Ingeniero Eduardo Torroja, con independencia de su ubicación.
- Promover la formación y especialización en todos los campos de las ciencias de la construcción y sus materiales que propongan innovaciones valiosas tanto en los aspectos técnicos como en los estéticos.

Se trata, en definitiva, de que la Fundación Eduardo Torroja sea una referencia en la difusión y debate de todos aquellos temas, tanto arquitectónicos como de ingeniería, que conforman la actividad de la construcción, promoviendo su adecuado desarrollo en nuestro país y contribuyendo, con ello, a un mejor conocimiento y valoración por parte de la sociedad.

\section{Patronos Fundadores}

-Agrupación de Fabricantes de Cemento de España (OFICEMEN).

- Asociación Española de Fabricantes de Hormigón Preparado (ANEFHOP).

- Asociación de Miembros del Instituto Eduardo Torroja (AMIET).

- Colegio de Ingenieros de Caminos, Canales y Puertos. -Confederación Nacional de la Construcción (CNC).

- Consejo Superior de los Colegios de Arquitectos de España.

- Consejo Superior de Investigaciones Científicas (CSIC).

$$
* * *
$$

\section{CONVENIOS DEL IETCC}

En este año 2004 el Instituto Eduardo Torroja ha firmado los siguientes convenios de colaboración:

- Convenio Marco con la Escuela Técnica Superior de Arquitectura de Madrid (UPM).

- Convenio Marco con la Escuela Universitaria de Arquitectura Técnica de Madrid (UPM).

- Acuerdo Marco con el Consejo General de Colegios Oficiales de Aparejadores y Arquitectos Técnicos.

- Convenio Marco con el Centro de Estudios y Experimentación de Obras Públicas (CEDEX) del Ministerio de Fomento. 